\title{
生理的食塩水静注の外リンパ電解質濃度 におよぼす影響
}

\author{
加納 直行* ・牧本 一男* \\ 大村 正樹**.八木 伸也***
}

\section{The Effect of Normal Saline Injection on the Concentration of Electrolytes in Guinea Pig Perilymph}

\author{
Naoyuki Kanoh, Kazuo Makimoto, \\ Masaki Ohmura and Nobuya Yagi \\ (Kyoto University)
}

Serum, cerebrospinal fluid (CSF), scala vestibuli perilymph and scala tympani perilymph were collected from 104 normal anesthetized guinea pigs (Sodium Pentobarbital $20-30 \mathrm{mg} / \mathrm{kg}$ I.P.) both before and after intravenous administration of normal saline $(1.5 \mathrm{ml} / \mathrm{kg})$, and the sodium and potassium concentrations were assessed using a microflame photometer.

Increase in the sodium concentration was observed in scala vestibuli perilymph, while there was no significant change in scala tympani perilymph, CSF and serum.

The potassium concentration did not significantly change in perilymph, CSF and serum.

The results of the present study indicate that a relatively small amount of injected normal saline affects the concentration of electrolytes in scala vestibuli perilymph. Thus, each perilymphatic space seems to have its own characteristic system in electrolyte transport.

\section{はじめに}

1954 年, Smith 等 ${ }^{1}$ が始めてモルモットの内, 外リンパ液を採取し, その電解質組成を測定して 以来, 多くの研究者がそれぞれの測定結果を発表している(2)345)6(7)8). その間，手術顕微鏡による 微細手術の進歩や電解質微量定量器機の精度向上, また定量技術の洗練により, 測定值に高度の再 現性が得られるようになって来た。てのような状況のもとに，蝸牛管リンパと卵形囊内リンパの間 の $\mathrm{Na}$ 濃度差, 鼓室階と前庭階の外リンパの $\mathrm{K}$ 濃度差などが次第に明らかにされた ${ }^{8)}$.また，一方 では, 内耳液電解質の微細な経時変動もとらえられるようになって来た ${ }^{9)}$.

近年, 内耳液電解質濃度に異常をもたらす要因が興味をもたれるようになっているが，ての研究

*京都大学医学部耳鼻咽喉科学教室（主任：桧 学教授)

**大津赤十字病院耳鼻咽喉科

***福井赤十字病院耳鼻咽喉科 
方向はメニエール病研究の一環として今後更に発展するものと思われる ${ }^{10)}$. 特に, 電解質の代謝, 輸送に有意の影響を示すといわれる各種利尿剂, 利尿ホルモン, 抗利尿ホルモン等についての研究 が着手されようとしていることは注目される.

我々もまた，乙の分野での幾つかの研究を企てているが9111)，今回は内耳液電解質動態に関する 研究の対照実験として次の実験を行なった. すなわち, 生理的食塩水の静注が内耳液電解質濃度に どのような影響を与えるかをモルシットを用いて実験し，検討を加えた。

\section{実 験 方 法}

実験動物にはプライエル耳取射正常のモル モット（300g〜500g） 104 匹を使用した。Sodium Pentobarbital を動物の腹腔内に投与 （20〜30 mg/kg）したのち，仰臥位におき頭部 を固定する. 次いで, 頸静脈を露出し, 生理的 食塩水 $(\mathrm{Na} 154 \mathrm{~m} \mathrm{Eq} / \mathrm{L}, \mathrm{Cl} 154 \mathrm{~m} \mathrm{Eq} / \mathrm{L}) 1.5$ $\mathrm{ml} / \mathrm{kg}$ を静注した．乙の条件下に中耳骨胞を開 き, 正円空より鼓空階外リンパ（Pt）を, 卵円 空より前庭階外リンパ $(\mathrm{Pv})$ を，それぞれ手術 顕微鏡下にマイクロマニプレーター操作により 採取した。一耳からは鼓室階外リンパまたは前 庭階外リンパのよ゙ちらかを一回の及採取した。 使用したマイクロピペットは尖端直径 5〜10 $\mu$ の屯ので, あらかじめ脱イオン水で充分洗浄し たあのを用いた．外リンパの採取時点は，生食 投与前（Before Injection）と投与後 15 分， 30 分, 45 分, 60 分, 90 分の 5 時点とし, 同一動物 で, できるだけ左右各耳で，連なる 2 時点で採 取した。乙の実験に使用した動物は, 鼓室階外 リンパ採取群 35 匹之前庭階外リンパ採取群 48 匹の合計 83 匹である。脸脊䯣液（C S F ) は Cisterna magna より手術顕微鏡下に同様にマ イクロピペットで採取した。 C S F の採取は, 同一動物において生食投与前 (Before Injec- tion）と投与後上記の 5 時点で経時的に行なっ

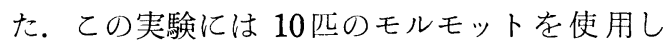
た。血液は大腿静脈等より採取し, 5000回転, 5 分間の遠沈により血清を分離した。血液の採 取むC S F の場合と同様に行なった。乙の実験 には11匹のモルモットを使用した。

得られた試料はすべてマイクロピペットの両 端をミネラルオイルで封入し, 化学分析を行う まで保存した。この時, 両外リンパ液につい て，血液との混入の有無を検討した，混入が認 められる場合は定量より除外した。

電解質 $(\mathrm{Na}, \mathrm{K})$ は, microflame photometer*を用いて微量定量した。 すなわち, 得 られた試料より正確に $1 \mu 1$ を取り，てれを $200 \mu 1$ の Lithium Blank に稀釈して測定を行なっ た。測定直前に，200 倍に稀釈された標準溶液 ( $\mathrm{Na} 140 \mathrm{mEq} / \mathrm{K} 5 \mathrm{mEq}$; Na $120 \mathrm{mEq} / \mathrm{K} 2 \mathrm{mEq}$ ; $\mathrm{Na} 100 \mathrm{mEq} / \mathrm{K} 100 \mathrm{mEq}$ ）で毎回調節を行な った.

上述の測定方法の再現性をみるために, 生理 学的食塩水 ( $\mathrm{Na} 154 \mathrm{mEq} / \mathrm{L})$ について, 同様 の手順で30回の測定を行なった。 その結果, 平 均值士標準䛊差はそれぞれ $157.0 \pm 0.69 \mathrm{mEq} /$ L, K 0.07士0.1mEq/L であった.

\section{実 験 結 果}

生理学的食塩水静注による外リンパ電解質濃 度の経時的変化を C S F, 血清の経時的変化と ともに図一 1 に総括して示した。

$\mathrm{Na}$ 濃度の変化をみると, 血清, C S F, 鼓
室階外リンパの曲線には有意の変動はみられな かったが, 前庭階外リンパの曲線は, 30分值以 降上昇を示したすなわち, 表一 1 に示す如く, 前庭階外リンパの投与前值 $131.84 \mathrm{mEq} / \mathrm{L}$ に対 


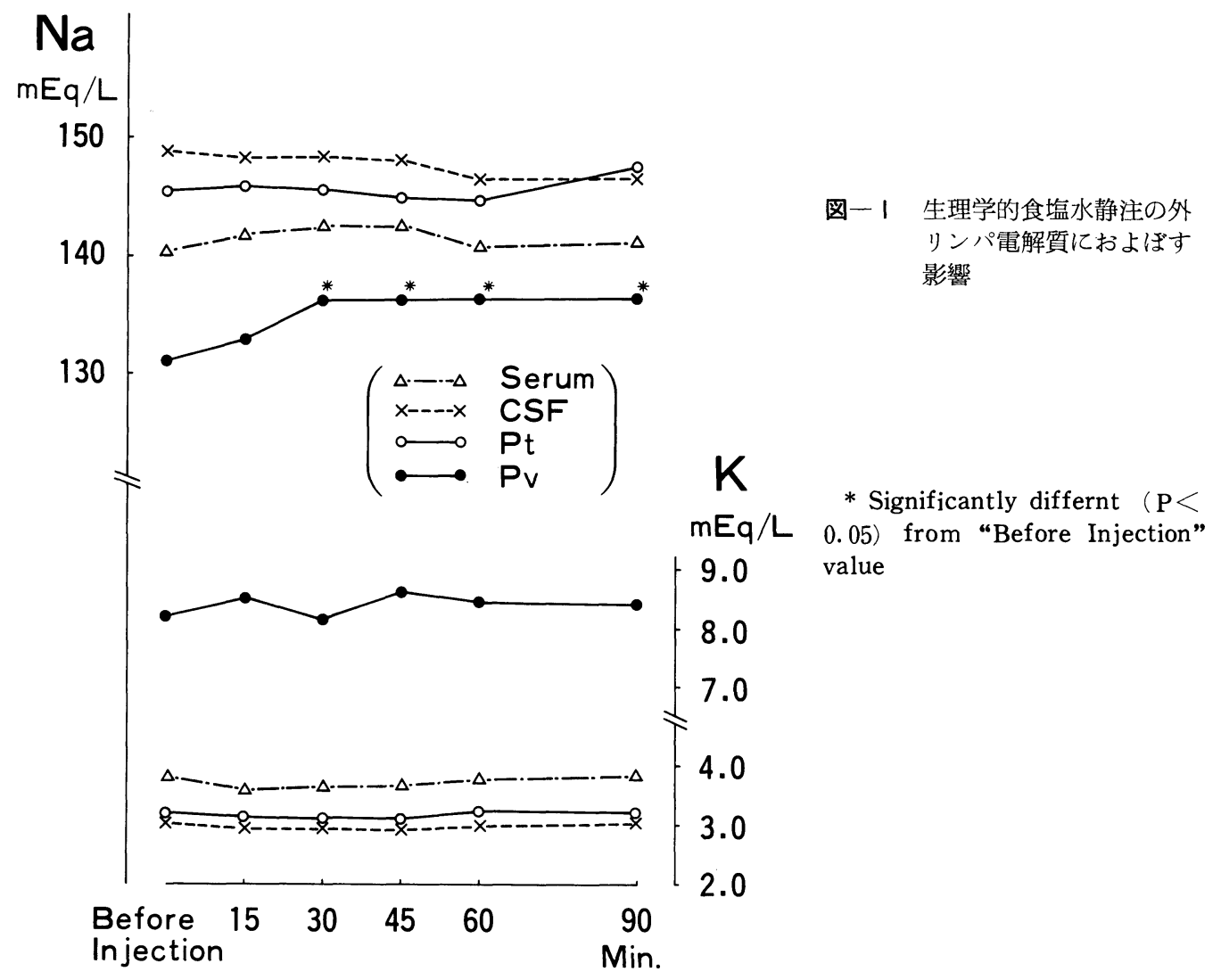

TABLE I

CHANGE OF SODIUM CONCENTRATION ( $\mathrm{mEq} / \mathrm{L}$ ) IN VARIOUS FLUIDS AFTER NORMAL SALINE INJECTION

\begin{tabular}{|c|c|c|c|c|c|c|}
\hline & Before Injection & $15 \mathrm{~min}$. & $30 \mathrm{~min}$. & $45 \mathrm{~min}$. & $60 \mathrm{~min}$. & $90 \mathrm{~min}$. \\
\hline Serum & $\begin{array}{c}140.48 \\
4.72 \\
(\mathrm{~N}=11)\end{array}$ & $\begin{array}{c}141.77 \\
4.97 \\
(\mathrm{~N}=11)\end{array}$ & $\begin{array}{r}142.77 \\
6.42 \\
(\mathrm{~N}=11)\end{array}$ & $\begin{array}{c}142.38 \\
5.69 \\
(\mathrm{~N}=11)\end{array}$ & $\begin{array}{c}140.58 \\
5.64 \\
(\mathrm{~N}=11)\end{array}$ & $\begin{array}{c}141.36 \\
5.33 \\
(\mathrm{~N}=11)\end{array}$ \\
\hline $\mathrm{CSF}$ & $\begin{array}{r}148.77 \\
3.62 \\
(\mathrm{~N}=9)\end{array}$ & $\begin{array}{c}147.53 \\
3.16 \\
(\mathrm{~N}=9)\end{array}$ & $\begin{array}{c}147.38 \\
1.81 \\
(\mathrm{~N}=9)\end{array}$ & $\begin{array}{c}146.14 \\
4.60 \\
(\mathrm{~N}=9)\end{array}$ & $\begin{array}{c}145.93 \\
2.85 \\
(\mathrm{~N}=9)\end{array}$ & $\begin{array}{c}145.41 \\
3.41 \\
(\mathrm{~N}=9)\end{array}$ \\
\hline $\begin{array}{l}\text { Perilymph of } \\
\text { scala tympani }\end{array}$ & $\begin{array}{c}145.85 \\
5.17 \\
(\mathrm{~N}=10)\end{array}$ & $\begin{array}{c}146.80 \\
4.11 \\
(\mathrm{~N}=10)\end{array}$ & $\begin{array}{c}145.60 \\
3.25 \\
(\mathrm{~N}=10)\end{array}$ & $\begin{array}{r}144.66 \\
5.43 \\
(\mathrm{~N}=10)\end{array}$ & $\begin{array}{r}144.77 \\
5.52 \\
(\mathrm{~N}=9)\end{array}$ & $\begin{array}{c}148.0 \\
5.21 \\
(\mathrm{~N}=11)\end{array}$ \\
\hline $\begin{array}{l}\text { Perilymph of } \\
\text { scala vestibuli }\end{array}$ & $\begin{array}{c}131.84 \\
3.24 \\
(\mathrm{~N}=11)\end{array}$ & $\begin{array}{c}132.71 \\
3.48 \\
(\mathrm{~N}=10)\end{array}$ & $\begin{array}{c}136.09 * \\
4.32 \\
(\mathrm{~N}=9)\end{array}$ & $\begin{array}{c}136.49 * \\
4.22 \\
(\mathrm{~N}=8)\end{array}$ & $\begin{array}{c}136.49^{*} \\
3.85 \\
(\mathrm{~N}=9)\end{array}$ & $\begin{array}{c}135.97^{*} \\
3.83 \\
(\mathrm{~N}=9)\end{array}$ \\
\hline
\end{tabular}

Data are expressed as a mean and standard deviation.

$\mathrm{N}$ represents numbers of data.

* Significantly diffent $(\mathrm{P}<0.05)$ from "Before Injection" value. 
TABLE II

CHANGE OF POTASSIUM CONCENTRATION (mEq/L) IN VARIOUS FLUIDS AFTER NORMAL SALINE INJECTION

\begin{tabular}{|c|c|c|c|c|c|c|}
\hline & Before Injection & $15 \mathrm{~min}$. & $30 \mathrm{~min}$. & $45 \mathrm{~min}$. & $60 \mathrm{~min}$. & $90 \mathrm{~min}$. \\
\hline Serum & $\begin{array}{c}3.82 \\
0.18 \\
(\mathrm{~N}=10)\end{array}$ & $\begin{array}{c}3.68 \\
0.10 \\
(\mathrm{~N}=10)\end{array}$ & $\begin{array}{c}3.70 \\
0.14 \\
(\mathrm{~N}=10)\end{array}$ & $\begin{array}{c}3.72 \\
0.30 \\
(\mathrm{~N}=10)\end{array}$ & $\begin{array}{c}3.82 \\
0.20 \\
(\mathrm{~N}=10)\end{array}$ & $\begin{array}{c}3.92 \\
0.32 \\
(\mathrm{~N}=10)\end{array}$ \\
\hline $\mathrm{CSF}$ & $\begin{array}{c}3.04 \\
0.35 \\
(\mathbf{N}=10)\end{array}$ & $\begin{array}{c}2.96 \\
0.35 \\
(\mathrm{~N}=10)\end{array}$ & $\begin{array}{c}2.96 \\
0.38 \\
(\mathrm{~N}=10)\end{array}$ & $\begin{array}{c}2.88 \\
0.17 \\
(\mathbf{N}=10)\end{array}$ & $\begin{array}{c}2.98 \\
0.07 \\
(\mathrm{~N}=10)\end{array}$ & $\begin{array}{c}3.06 \\
0.39 \\
(\mathrm{~N}=10)\end{array}$ \\
\hline $\begin{array}{l}\text { Perily mph of } \\
\text { scala ty mpani }\end{array}$ & $\begin{array}{c}3.12 \\
0.40 \\
(\mathrm{~N}=10)\end{array}$ & $\begin{array}{c}3.12 \\
0.39 \\
(\mathrm{~N}=10)\end{array}$ & $\begin{array}{c}3.06 \\
0.52 \\
(\mathrm{~N}=10)\end{array}$ & $\begin{array}{c}3.02 \\
0.15 \\
(\mathrm{~N}=10)\end{array}$ & $\begin{array}{c}3.22 \\
0.38 \\
(\mathrm{~N}=9)\end{array}$ & $\begin{array}{c}3.04 \\
0.52 \\
(\mathrm{~N}=11)\end{array}$ \\
\hline $\begin{array}{l}\text { Perily mph of } \\
\text { scala vestibuli }\end{array}$ & $\begin{array}{c}8.36 \\
1.03 \\
(\mathrm{~N}=11)\end{array}$ & $\begin{array}{c}8.65 \\
0.75 \\
(\mathrm{~N}=13)\end{array}$ & $\begin{array}{c}8.27 \\
0.82 \\
(\mathrm{~N}=9)\end{array}$ & $\begin{array}{c}8.70 \\
0.56 \\
(\mathrm{~N}=8)\end{array}$ & $\begin{array}{c}8.51 \\
0.83 \\
(\mathrm{~N}=9)\end{array}$ & $\begin{array}{c}8.53 \\
1.08 \\
(\mathrm{~N}=9)\end{array}$ \\
\hline
\end{tabular}

Data are expressed as a mean and standard deviation.

$\mathrm{N}$ represents numbers of data.

し, 30 分值 $136.09 \mathrm{mEq} / \mathrm{L}, 45$ 分值 136.49 $\mathrm{mEq} / \mathrm{L}, 60$ 分值 $136.49 \mathrm{mEg} / \mathrm{L}, 90$ 分值 135.97 $\mathrm{mEq} / \mathrm{L}$ と各々，投与前值に対して有意差を認 めた，K濃度の変化をみると（表一 -2 に測定結

考

生理的食塩水を頸静脈より注入した場合，前 庭階外リンパで $\mathrm{Na}$ 濃度の軽度の上昇が認めら れたが，血清，CS F, 鼓室階外リンパでは有 意の変化がみられなかった。ここで，前庭階外 リンパと鼓室階外リンパの $\mathrm{Na}$ 濃度の各測定值 の全てについてみると図- 2 , 図一 -3 の如くに

前庭階外リンパのナトリウム

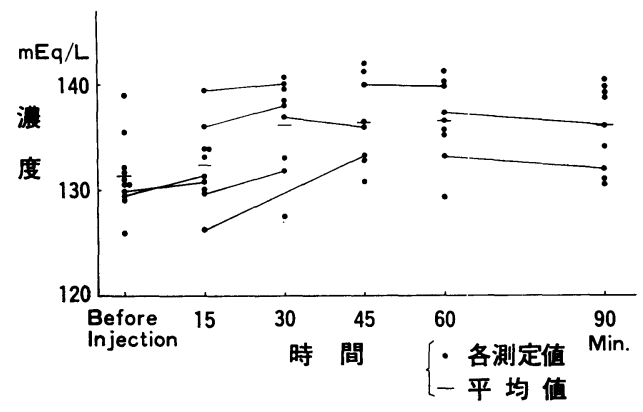

図一 2
果の数値を示した), 血清, C S F, 鼓室階外 リンパ，前庭階外リンパのすべての曲線に有意 の変動はみられなかった。

按

なる，図で横線で結ばれた各点は同一動物に 対して左右各耳より採取した場合の測定値を示 している. 図一 2 に示すように, 前庭階外リン パの $\mathrm{Na}$ 濃度は, 平均值でみた場合（図一 1 , 表一1）と同じく, 生理的食塩水静注後30分以 降上昇している傾向が認められる。 しかし, 図

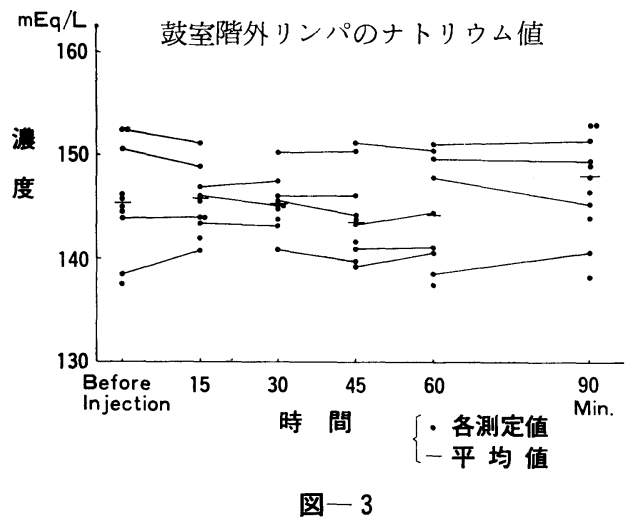


- 3 に示すように鼓室階外リンパの $\mathrm{Na}$ 濃度に は変化は認められない。

Silverstein and Takeda ${ }^{12)}$ (1970)は, 高調 食塩水 $(\mathrm{Na} 350 \mathrm{mEq} / \mathrm{L}, \mathrm{K} 5 \mathrm{mEq} / \mathrm{L})$ をネコ の頸動脈より, $260 \mathrm{ml} / \mathrm{h}$ の速度で持続注入した 実験を行なっている，彼等の報告では，1) Na 濃度の上昇は鼓室階外リンパで最む著明にみら れる，2）前庭階外リンパ及び，両内リンパ (蝸牛管, 卵形囊) では, その值が一度上昇し た後20分から40分で正常レベルに下降し，その 後, 増減を示しつつ推移する,などの所見が 記載されている。我々の生食静注実験とは, Silverstein 等の実験が高調食塩水であること, ネコであること，Kの負荷があること，持続動 注であるととなど多数の異なる点がある．との ように食塩水負荷実験でも, 条件の違いにより 電解質の動態は大きく違ってくるととに注意し なければならない，今回の実験では前庭階外り ンパの $\mathrm{Na}$ 濃度にのみ変化がみられたととにな る.

一方, 我々が行なったグリセロール負荷実 験9)(1981) では, 血清, C S F, 鼓室階外リン パの $\mathrm{K}$ 值には変動はなく, 前庭階外リンパの $\mathrm{K}$ 濃度のみ上昇を認めた。乙れらの結果をあわせ て考えると前庭階外リンパ空は, C S F, 鼓室 階外リンパ腔とは, 電解質の膜輸送や代謝の面
で異なった側面を有する特有な体腔であると推 察できる.

さて, この内耳液電解質動態に関する研究で は, しばしば電解質の代謝, 膜輸送に影響する 各種物質の静注実験が行なわれる.今回の我々 の生理的食塩水静注の実験は, この種の実験の 対照実験として企画されたものである。乙れま での報告では循環血液中に液体を注入する場 合，体腔は注入された液体の浸透圧と量によっ て影響を受けるといわれている，また，ての 際, 血行力学的変化による影響を同時に受け る. 今回の実験では，前庭階外リンパは，比較 的小量の生理的食塩水の静注に対しても反応を 示した。乙の事は上述の体液調節機構における 一事象としてみることができる，各種薬物注入 時の電解質代謝, 膜輸送に関する研究で生食静 注実験を対照として用いることがあるが，上記 の成績はこの方法には注意が必要であるととを 示している.

また，臨床的には，次の点で貴重な資料とい える.すなわち，今回得られた成績より推察す ると, 人工透析に際して内耳液電解質は有意に 変動する可能性がある. 従来, 人工透析に起因 して聴覚障害 ${ }^{13)}$ や前庭障害 ${ }^{14)}$ がおてることが報 告されているが，その機序の説明をてのような 角度から行うことあ考えられてよいと思う。

\section{ま と め}

生理的食塩水静注実験の結果，前庭階外リンパで有意に $\mathrm{Na}$ 濃度が上昇することがわかった。乙 の所見は, 比較的少量の生理的食塩水静注の場合でも, 前庭階外リンパは反応し, 電解質濃度が変 化する事を示している. 各種薬剤を用いる内耳液電解質動態に関する研究において, 生理的食塩水 静注実験を対照として使用するてとがあるが，その成績の判定にあたっては上記の事実は特に留意 する必要がある.

また，前庭階外リンパ腔の持つての電解質動態上の特異性についてその生理的意義を今後更に明 らかにして行かねばならない.

本論文の一部は第81回日耳鼻総会において発表した。

稿を終わるにあたり，御校閲を賜りました桧学教授に深謝いたします。 


\section{参考 文 献}

1) Smith, C.A., Lowry, O.H. and Wu, H.L. : The electrolytes of the labyrinthine fluids. Laryngoscope $64: 141 \sim 153,1954$.

2 ) Citron, L., Exley, D. and Hallpike, C. S. : Formation, circulation and chemical properties of labyrinthine fluids. Brit. Med. Bull. 12 : 101 106, 1956.

3 ) Rauch, S. and Kostline, A: Aspects chimiques de l'endolymhe et de la perily mph. Pract. Otorinolaryngol $20: 287 \sim 291,1958$.

4) Johnstone, C.G., Schmidt, R.S. and Johnstone, B.M. : Sodium and potassium in vertebral cochlear endolymph as determined by flame microspectrophotometry. Comp. Biochem. Physiol. $9: 335 \sim 341,1963$.

5 ) Silverstein, H. : Biochemical studies of the inner ear fluids in the cat. Arın Otol. 75 : 48〜63, 1966.

6) Bosher, S.K. and Warren, R.L. : Observations on the electrochemistry of the cochlear endolymph of the rat: a quantitative study of its electrical potential and ionic concentration as determined by means of flame spectrophotometry. Proc. Roy. Soc. B. |7| : 227 247, 1968.

7 ) Rodgers, K. and Chou, J.T.Y. : Concentrations of inorganic ions inguinea pig inner ear fluids. 1) Concentration of potassium and sodium in cochlear and utriclar endoly mph.

J. Laryng. $80: 778 \sim 790,1966$.

8 ) Makimoto, K. and Silverstein, H. : Sodium and potassium concentrations in the endo lymph of the cat. Ann Otol. $83: 174 \sim 179$, 1974.

9 ) Kanoh, N., Yagi, N., Ohmura, M. and Makimoto, K.: Effects of glycerol on sodium and potassium concentrations in guinea pig perily mph. Arch Oto-Rhino-Laryngol. 230 : 177 180, 1981.

10) Williams, H. L. : A review of the literature as to the physiology dysfunction of Meniere's disease.: A new hypothesis as to its fundamental cause. Laryngoscope $75: 1661 \sim 1688$, 1965.

11) 加納直行, 牧本一男: Furosemide の内耳液電解 質濃度におよぼす影響, 厚生省特定疾患メニエー ル病調査研究班報告, 1980年.

12) Silverstein, H. and Takeda, T. : Sodium loading of inner ear fluid. Ann Otol. 85:769 775, 1976.

13) Yassin, A., Badry, A. and Fatt-Hi, A. : The relationship between electrolyte balance and cochlear disturbances in cases of renal failure. J Laryng. $84: 429 \sim 435,1970$.

14) Yassin, A., Badry, A. and Fatt-Hi, A. : The role of electrolyte balance on vestibular disturbances in cases of renal failure. $\mathrm{J} \mathrm{La-}$ ryng. $84: 437 \sim 442,1970$.

原稿到着: 昭和 56 年 3 月 2 日
別刷請求先: 加納直行
T606 京都市左京区聖護院川原町
京都大学医学部耳鼻咽喉科学教室

